\title{
Picturing Megaliths in Twentieth- Century Swedish Archaeology
}

\author{
Cornelius Holtorf
}

"A picture says more than a thousand words"
folk wisdom

In this paper I will begin a discussion about the ways in which megaliths appear in archaeological images. My discussion of examples is not comprehensive and the selection of images far from complete, but I hope nevertheless to present some key elements of the pictorial vocabulary with which megaliths have been seen and depicted by archaeologists working in Sweden during the twentieth century. However, entering the third millennium of our chronometrical timescale should not only be an occasion to look back, but also an opportunity to look forward and reflect upon the way ahead. Recent discussions about the problems with established ways of depicting archaeological sites and objects, and suggestions for new kinds of images and illustrations, should concern us all and lead to an active engagement of archaeologists with questions of visual (re)presentation.

Cornelius Holtorf, Department of Archaeology, University of Cambridge, Downing Street, Cambridge, CB2 3DZ. United Kingdom.

\section{READING ARCHAEOLOGICAL}

IMAGES

Over the last few years scientific illustrations and images have started to attract a good deal of interest among historians and philosophers of science (Ellenius 1985, 1990; Lynch \& Woolgar 1990; Baigrie 1996) as well as among archaeologists (Molyneaux 1997; Moser 1999). In archaeology, such an interest forms part of a wider trend to study the practices and products of archaeology with the same attention given to what happened in the past. A current doctoral dissertation is, for example, concerned with "Words and Pictures: Images as discourse in archaeology" (Bateman in preparation). Investigating the changing aesthetics of archaeology complements studies of its poetics, and contributes to a better understanding of archaeological rhetoric. It is obvious that the right choice of images has always been, and still is, as important to becoming a successful researcher and author as is the right choice of words. Archaeological images thus offer valuable information on the history of archaeology (Nordbladh 1997) and the principles of its current discourse (Shanks 1997).

Of particular importance for archaeology has been the advent of photography in the late nineteenth century. Early commentaries celebrated photographs as providing archaeologists with 'accurate', 'authentic', and 'exact' representations of archaeological sites and objects (cited from Trotzig 1987). Since then, it has repeatedly been emphasised that photographs too are a form of art and anything but truthful and accurate representations of reality. Photographs are not only de- 
pendent on codes and conventions that can convey complex messages about the social, cultural and intellectual context of both the photographer and the original audience, but they are also subject to manipulation and deception, whether intended by the photographer or not (Trotzig 1987; Shanks 1997; Bateman in preparation).

The various genres of archaeological images and the ways in which changing paradigms and approaches found their expression in different sorts of images have been discussed elsewhere (e.g. Piggott 1978; Trotzig 1990; Bradley 1997; Moser \& Gamble 1997). Rather than showing these typologies and connections at the example of a specific class of monuments once again, I find it more interesting to focus in greater detail on the aesthetics of megaliths in the archaeological images themselves. While the 'Neolithic' and 'megaliths' in texts have recently been subjected to critical analysis (Thomas 1993; Tilley 1998), their depictions in images are often taken for granted and have remained largely unquestioned. In this paper I will begin a discussion about the ways in which megaliths appear in archaeological images. It is only appropriate in the present journal and its first issue of the new millennium that $I$ restrict my examples to twentieth-century Swedish archaeology. Of course it is deeply ironic, if not completely self-defeating, to try and write about images. But this paper is not intended as a written commentary on pictorial illustrations. I rather consider it as a collection of written illustrations of pictorial commentaries. My words only illustrate what the images say.

\section{MORE THAN A THOUSAND WORDS}

My survey of the images of megaliths in twentieth-century Swedish archaeology cannot be comprehensive and is far from complete. In fact, the selection of images reproduced here is ultimately arbitrary and based on advice and assistance I was given (notably by Karl-Göran Sjögren), on sources available in the University Library and the Archaeological Institute Library in Göteborg, and on my own judgement and taste. Having said that, I suspect that the images selected nevertheless give a larger picture, too, and show some key elements of the pictorial vocabulary with which megaliths have been seen and depicted by archaeologists working in Sweden during the last century.

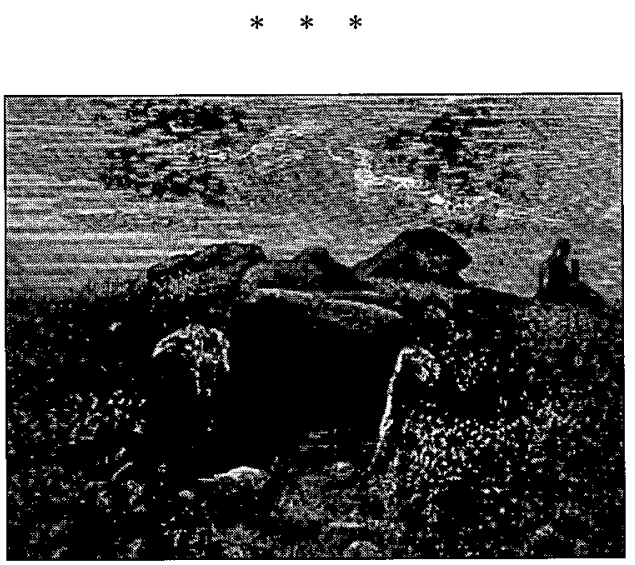

Fig. 1. From Montelius 1910:fig. 22. Woodcut signed 'W. Meyer'.

This woodcut originated in an atelier, but it is based on one of the earliest archaeological photographs in Sweden, taken by Gustav Retzius in ca. 1872 (Trotzig 1987, 1990:fig. 8). Reproduced in 1910 , it stands in this paper for a continuity of picturing megaliths since the nineteenth century, and for the beginnings of the use of photography in modern archaeological documentation. The image depicts the megalith at Karleby 'objectively'. But it expresses also some of the Romantic atmosphere in which many early investigations of megaliths were conducted, or with which they wanted to be associated. Days spent in the countryside, excavating antiquities while smoking a pipe. The image may seem innocent, inasmuch as it includes all the elements which made, and make, such investigations pleasant but which are so often now excluded from illustrations of archaeological investi- 
gations: the mystery of the (still) untouched monument, the nice weather, the lush vegetation, the good company, and the relaxed time schedule of the dig, allowing time for the (then) lengthy procedure of taking pictures, and for resting. However, we know that the scene was in fact carefully constructed. Johan of Skultas, who was 19 years old when he worked for Montelius and Retzius in Karleby, remembered in 1935:

"They wanted me to be in the photo of the Klövagård grave, they said it would give 'a bit of life' to the picture. So that's me, sitting on the hill and smoking a pipe, for it was always hanging from my mouth when I was a boy" (cited after Strinnholm 1995:18; translated by Laura Wrang; identification of the megalith described here with the one shown in the picture according to Tony Axelsson, pers. comm.).

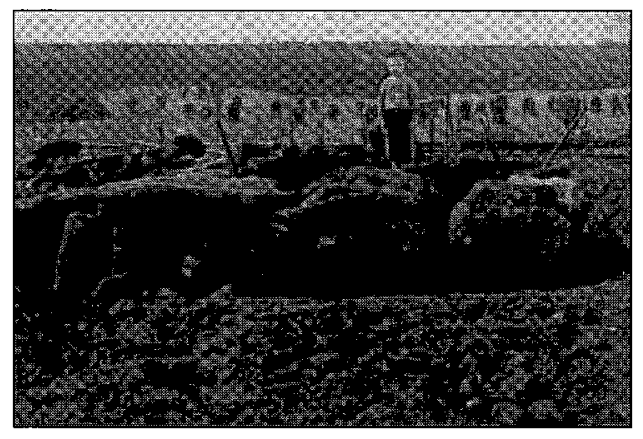

Fig. 2. From Lindqvist 1911:fig. 3. Photograph by Sune Lindqvist.

This image evokes emotions today because of the little boy standing patiently and with a clear sense of duty behind the grave of some (very) distant forebears. The boy served as no more than a scale for the picture and this was a perfectly common motif at the time. But because we are not used to seeing children (or any people) on archaeological images today, we are left wondering whether he is the son of an archaeologist, or a boy from the village, or even a regular worker.
At the stone cist, work is in progress and only the foreground seems to have been cleaned up for the picture. The boy emphasises nicely the vertical elements in the upper part of the picture, although the overall emphasis is on horizontal lines formed by the stones of the grave, the fields in front of as well as behind it, and by the forest and the skyline in the far distance.

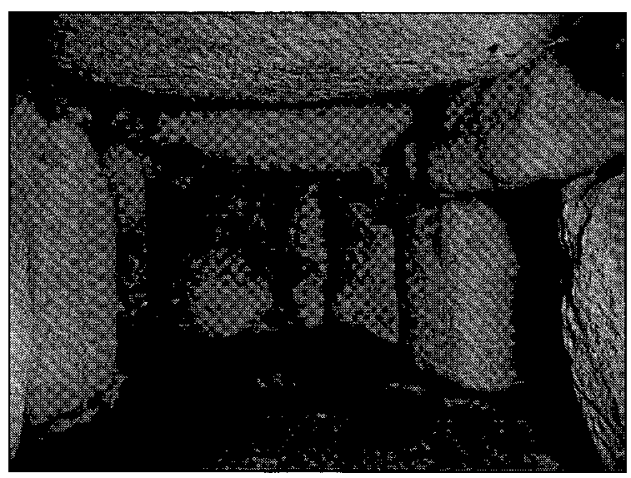

Fig. 3. From Rydbeck 1932:fig. 6.

The inside of the passage grave at Gillhög. The photograph shows clearly the layout and architectural details of the chamber and thus reflects the attention those aspects have received in twentieth-century archaeological research, not only in Sweden. But the image is also deceptive. Neither a modern visitor nor a prehistoric person will have seen the place like this. While in the past access to the grave chamber is likely to have been very restricted and burials would have occupied much of the ground, nowadays you would expect some rubbish lying around in a place like this and a few plants growing along the edges of the stones (a little natural light coming in through the open passage). This view does not show a timeless megalithic burial site but a place at a very specific point of time: after the chamber had been investigated and cleaned by archaeologists, and while it was illuminated for the benefit of the photographer by an artificial source of light somewhere to the right of the camera. 


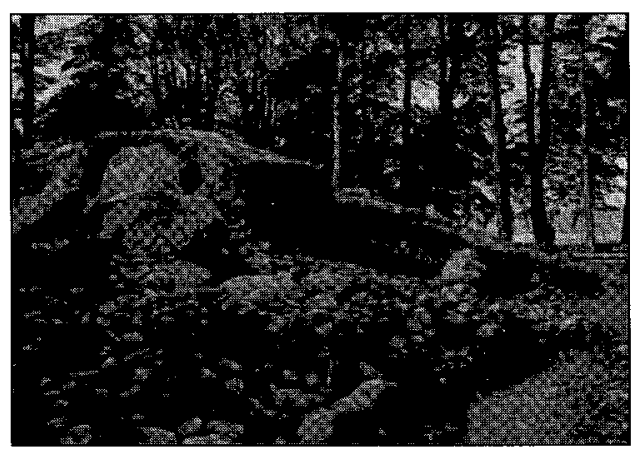

Fig. 4. From Forssander 1936:fig. 8.

This is the same megalith as in the previous picture, but from the outside and while being excavated by archaeologists. The chamber is hidden from view by large boulders and a mound. While the foreground has been cut off, the photographer chose to have part of the picture taken up by trees in the background. Apart from these trees, the image shows the site as being stripped from everything except stones and earth. The outside of the tomb thus shares artificial cleanliness and lifelessness with the inside. The excavation trenches on the right are strictly rectangular and the sections have been neatly cut: military precision that is often considered a hallmark of scientific methodology in archaeology. Rather than the photo showing the site as it looked to the archaeologists, the site was obviously prepared by archaeologists to look 'good' in the photograph - a standard practice still today.
Fig. 5 is an aquarelle by the architect Ferdinand Boberg and presents a strikingly atmospheric view of a dolmen - well suited to the patriotic spirit of the book which contains several other aquarelles in the same style. The contrast between the large, resting stones and the disturbed sky makes this image almost come alive. The situation is so true of some of my own experiences of visiting megaliths in Scania (and elsewhere) that I can almost feel the cold wind blowing against my face, smell the sea, and see the old cow shit among the grass in the field. We would not expect something similar from a 'scientific' illustration, but that only means that some key aspects of experiencing megaliths are lost in them. The original image is in colour, and therefore even more vivid. A comparison between the colour original and the blackand-white reproduction here reveals what is lost through the technical and financial limitations that prevent more colour reproductions in archaeology.

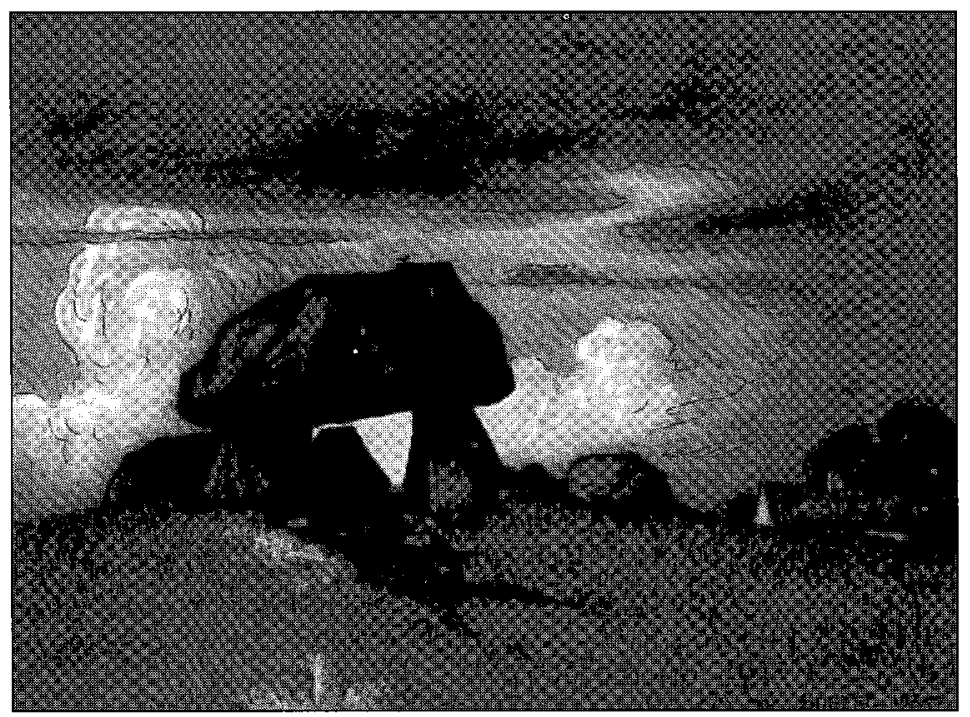

Fig. 5. From Wrangel 1938:after p. 40. Aquarelle by Ferdinand Boberg 1935; original in the Antiquarian Topographical Archive, Stockholm. 


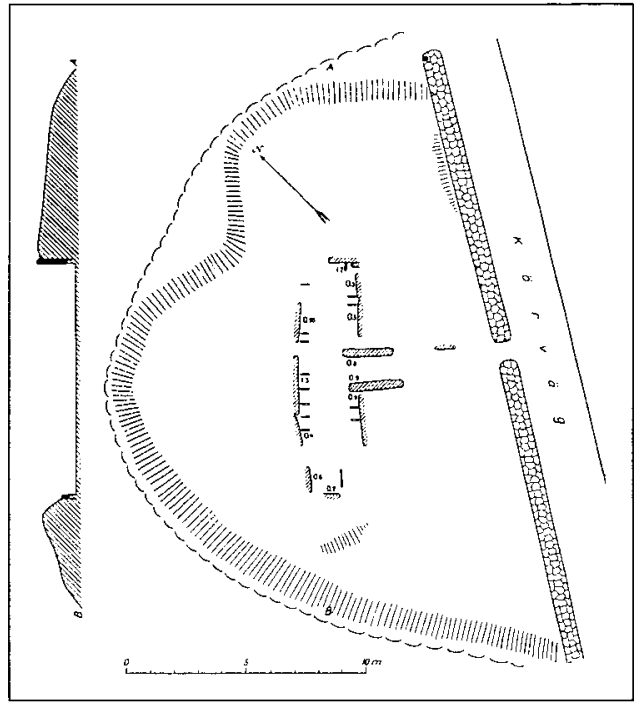

Fig. 6. From Sahlström 1939:fig. 7. Drawing by K. E. Sahlström 1935.

The image shows lines of varying thickness forming different shapes, as well as numerals and letters in various fonts and sizes. Archaeologists (and other skilled plan readers) can learn a great deal from this figure without investing too much thought in it, because the ability to 'read' illustrations like this is part of their discursive knowledge. They can see immediately where the (modern) road is and how far the (ancient) mound extended; they see where the chamber and passage of the grave are located and how the chamber looks today; they understand what happened to the mound when the road was built; they know that two fairly peculiar features could in fact have been placed anywhere on the plan and are a scale and a north arrow respectively. Curiously, archaeologists are unlikely to miss in this image representations of other elements which are equally important for an archaeologist working at the site: trees and other vegetation, the spoil heap, vehicles, the (direction to the next) toilet, paths used, and so on.

Fig. 7 is an interesting combination of photograph and plan. The image is based on a photograph taken by a photo-tower from high above the grave; lines and figures were later superimposed in high contrast. The photo-

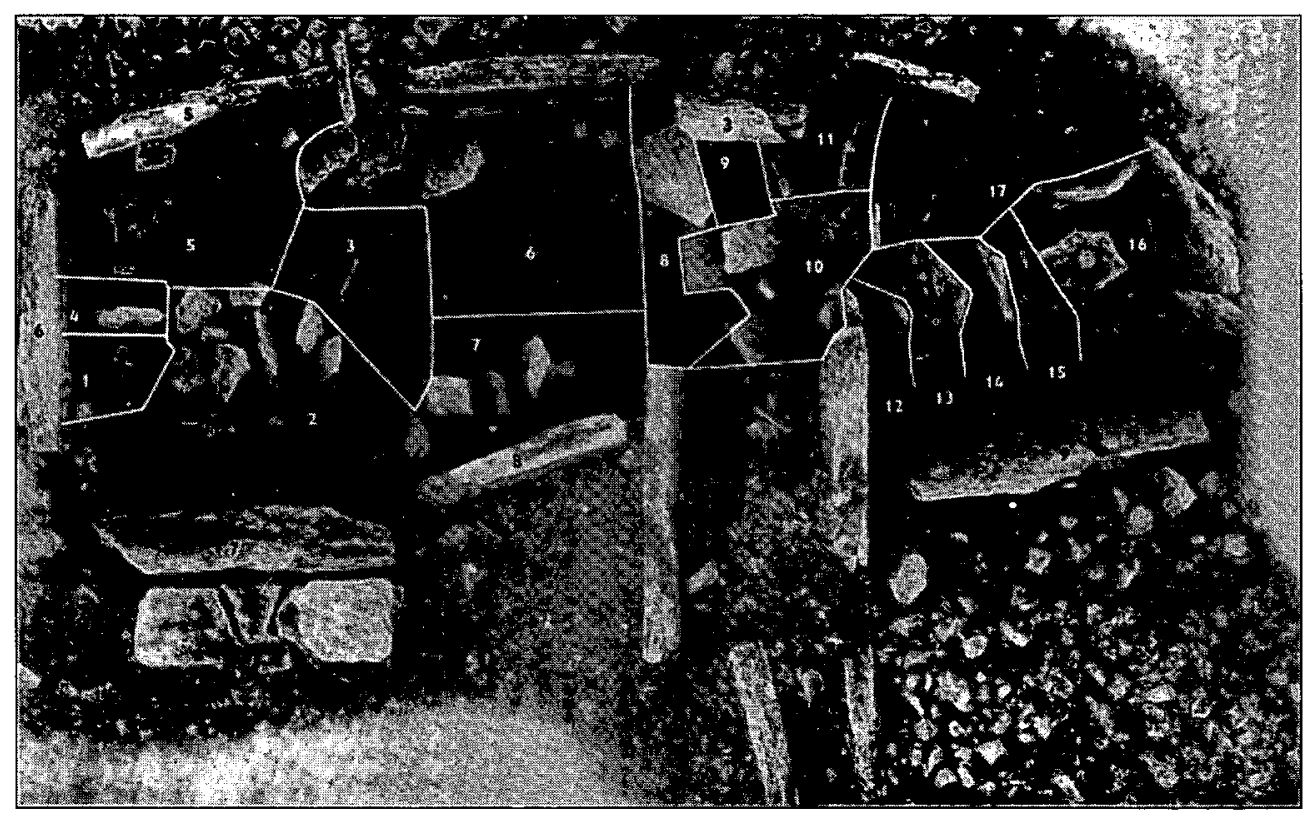

Fig. 7. From Cullberg 1963:fig. 3. 
tower is a very peculiar invention. It allows the archaeologist to take a (real) picture from the same (imaginary) 'bird's eye' perspective from which ground-plans are usually drawn. The layout of the burial chamber is well visible, as are its internal features, some human bones, and the remains of a cairn around it. However, other parts of the picture on two sides seem to have been deliberately bleached as if something depicted there was not meant to appear in the printed figure.

Fig. 8 shows a part of a larger section drawing from an excavation. Presumably the stones were not actually cut through (but how can we be sure from the image?). The archaeological and geological information conveyed is schematized, encoded in various geometric patterns, and presumably limited to the clearly discernible patterns, while leaving out a lot of confusing (or crucial?) details (cf. Bradley 1997). The text is in German, as (especially southern) Swedish archaeology has a long tradition of publishing in foreign languages, now predominantly English as in this journal. Since archaeologists work below the surface and underground, nothing is shown above surface level, even though it is likely that a few measuring devices and some vegetation were in fact located exactly along the line of the section. At certain points of time while the drawing was made, people may have stood on the edge of the section, or tools could have been lying there. On the other hand, what is shown above the surface, a few numerals and letters, has not been visible to the archaeologist who did the drawing.

Fig. 9 is a photograph showing the same dolmen while under excavation. The atmosphere in this piture of an ancient burial site is one of tranquility and timelessness. A bit like a Japanese garden - were it not for the modern houses that can be seen along the horizon, and a few measuring poles standing in the fields. The genre of pictures showing free-standing prehistoric stone chambers in an open landscape of arable fields is one of the most popular in archaeological publications. While some may insist that if you have seen one megalith you have seen them all', for others the fascination remains with every well-preserved example that imposes its massive presence onto the modern land-
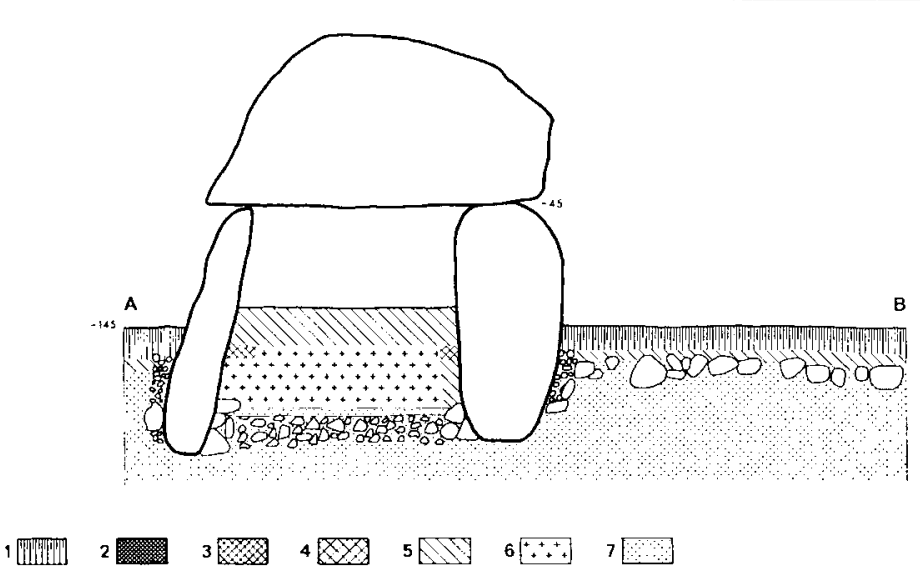

Abb. 3. Profile. Zeichenerklärung: $\mathrm{I}=$ sandvermischter Humus. 2 - Russ und kleine Holzkohlestücke. 3 … stark russvernischter Sand. 4 = schwach russvermischter Sand. $5=$ schwach humusvermischter Sand. $6=$ umgewühlte Schicht. $7=$ gelber Sand.

Fig. 8. From Strömberg 1968:fig. 3. Drawing by Bertil Centerwall. 


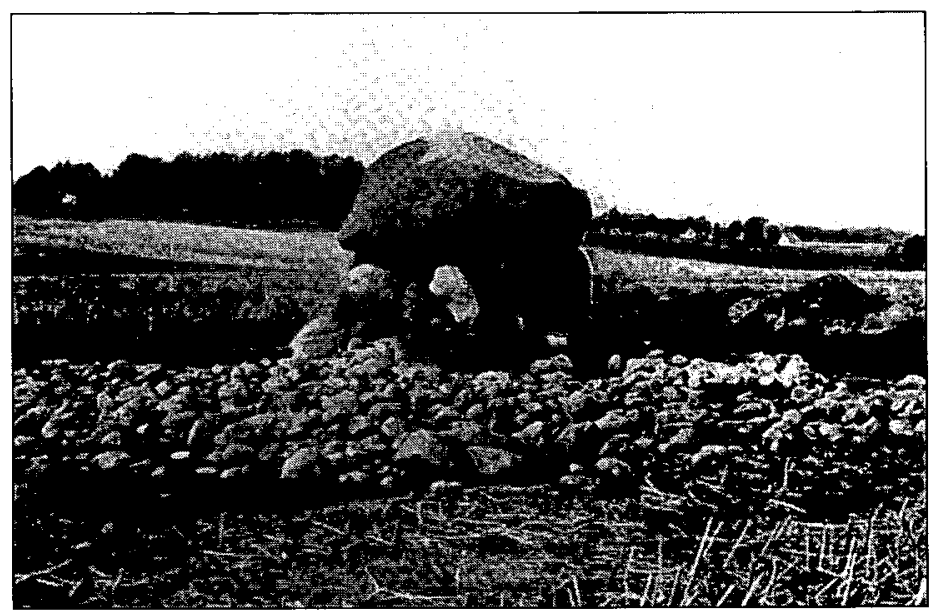

Fig. 10 is another drawing from the same excavation report. Shown are the outlines of the grave, the stone paving to the east and to the west, and another extension of stones to the south, all covered by a square meter grid. The grid can also be taken to represent the 'grip' of Science; rectangular perfection bringing a site under control.

Fig. 9. From Strömberg 1968:fig. 15.

scape. In this picture, the boulders forming the dolmen appear even larger when seen with the small stones around them.
Everything is fitted into the exact schemes of methodology and subjected to rigorous analysis and numerical precision. What looks like a planetary system in the centre of the picture illustrates in fact the location and quantity of sherds in relation to the single

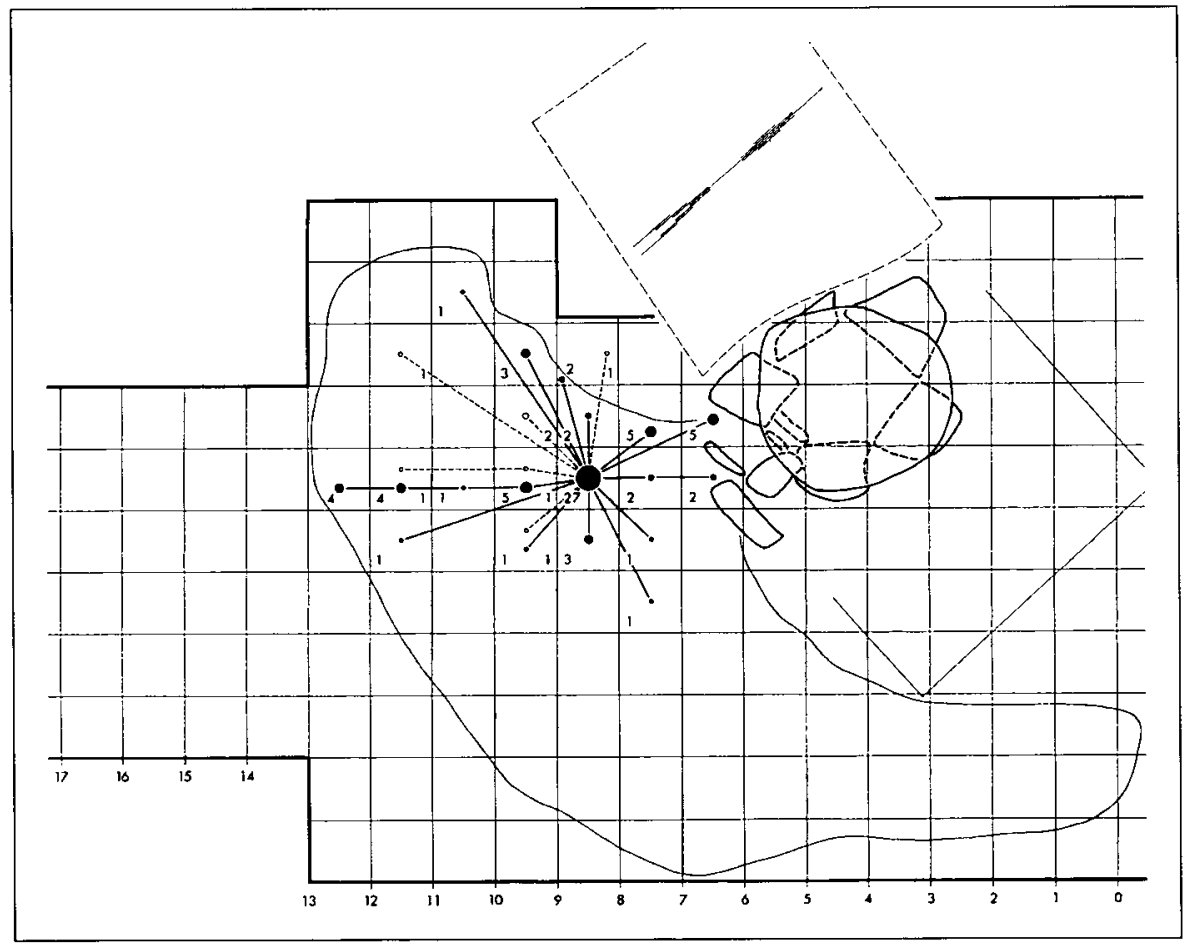

Fig. 10. From Strömberg 1968:fig. 91. Drawing by Bertil Centerwall. 
pot no. 64 from which they originated. Above this scene of dispersal and home-coming is a space rocket (in the area of the western stone paving) indicating North. Almost all the lines and numbers in this drawing are non-existent to an observer at the site itself.

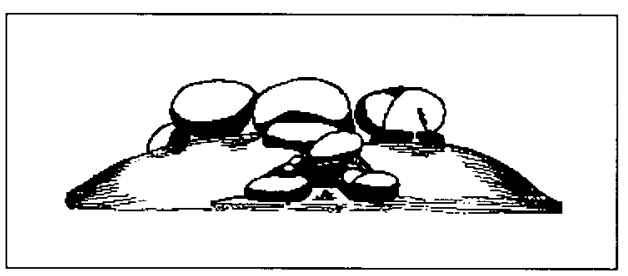

Fig. 11. From Strömberg 1972:Title-page. Unknown artist.

A megalith in the style of a woodcut on the title-page of an excavation report. Black-andwhite at its best. As an emblem or logo of the report, the little drawing refers promi- nently to the non-textual, material dimension of the excavation published here. Almost like a company logo, the image creates a single identity for the site and the report. We know immediately what this book is about, although we are left in the dark as to how the topic is approached. Although the design of the title-page is not unique, we may suspect from the use of an emblem on the title-page, printed directly beneath the name of the excavator, that she too identified with the site, the report, and its logo. The archaeologist herself, the role of interpretation in the project, and the 'problematics' mentioned in the book title are, however, ignored in the picture.

Fig. 12 is a beautifully drawn image of a megalith, with some measurements, horizontal and vertical cross-sections, and the original locations of a number of burials, but

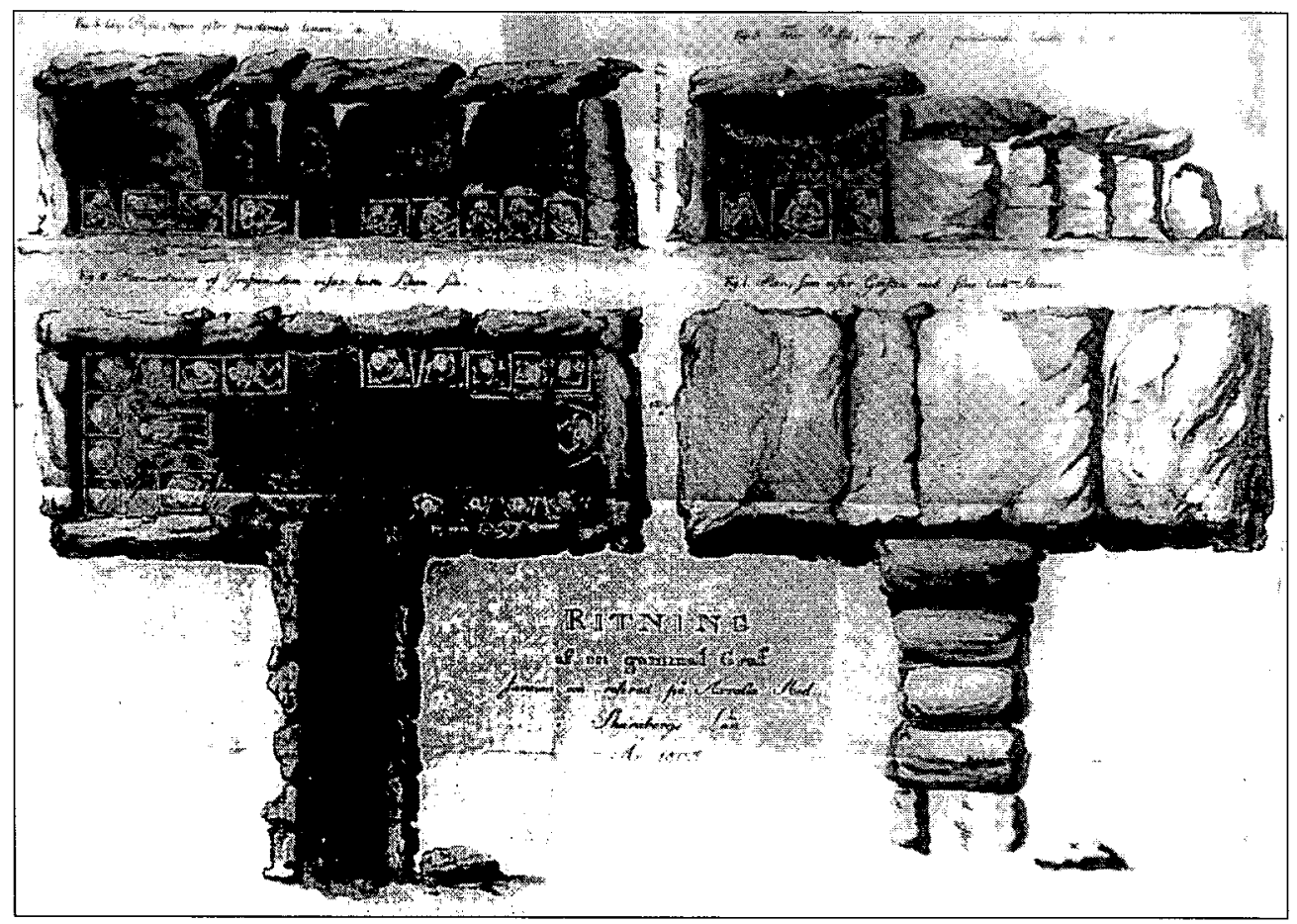

Fig. 12. The passage grave "Odin's grave", Axevalla. Drawing by A. Lindgren 1805. First published in Nya handlingar af Kongl. wettenskaps och witterhets samhället i Götheborg 1806, with a description in the same series 1808, pp. 87-103. Original in the Antiquarian Topografphical Archive, Stockholm. 
ignoring the mound around the monument. The drawing was made at the beginning of the nineteenth century by the artillery officer A. Lindgren, when he received orders to document the passage grave before it was to be removed for the extension of a military exercise area - without the proper antiquarian authorities being informed (Trotzig 1990:108-109). The beautifully executed drawing, its military precision, and the artful writing on it contribute to the aethestic pleasure which this image still conveys. In slightly different versions, this drawing was very frequently reproduced throughout the twentieth century, also outside Sweden, and is thus included here (at an arbitrary point, although I originally came across it in a publication from 1987). Lindgren's image has clearly become a 'classic' of Swedish archaeology and is the equivalent to an old essay or book which is often cited. Like many written reports, images of archaeological sites or objects do not automatically lose relevance and value through time, but continue to be used as sources of information and key reference points for particular research topics.

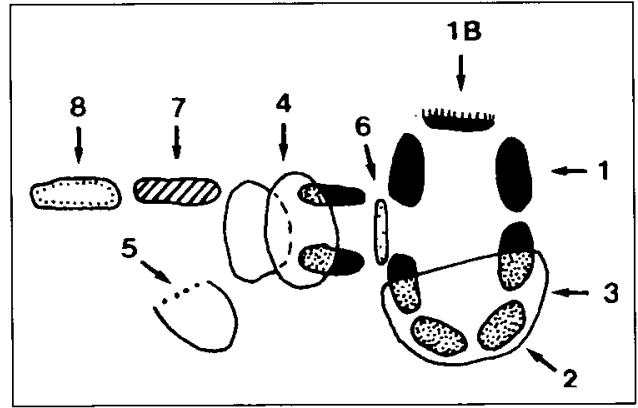

Fig. 13. From Blomqvist 1989:228 (Appendix X).

A generic megalith is sketched here, which in all likelihood does not exist anywhere in this form. The image defines a pictorial vocabulary for an extensive catalogue of plans of megaliths. As soon as the eight semantic codes are understood, all plans become instantly readable (in its original place the numbers in this explanatory image are de- coded directly below the image). Unlike a photograph, the pictorial language can show stones even where they are hidden by other stones (numbers 2 and 4), and even after they have long disappeared from their original location but are reconstructed from old plans or excavation results (numbers 7 and 8 ).

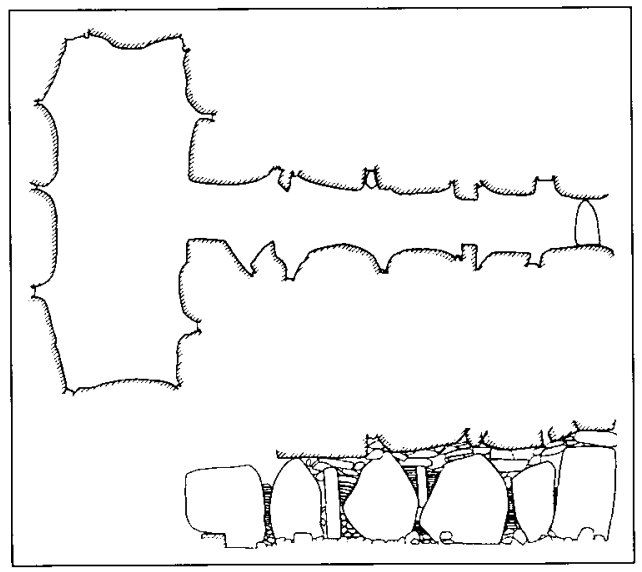

Fig. 14. From Hårdh 1990:fig. 3.

A drawing of a passage-grave interior. The ground-plan does not resemble a bird's eye perspective, although it is drawn as if looking down. It is rather the perspective of a person inside a dark mound, crawling on the floor and feeling for the boundaries of the stones. But apart from a single entrance, now blocked, there is no gap - no escape. How far each stone extends into the mound remains unknown. Below, the section through the passage is depicted in a way showing the architectural features, but it is interesting how the cap-stones are only hinted at - again it is the perspective of someone inside the tomb, carefully observing the surroundings, now with light falling in. The view of the outside observer $\mathrm{x}$-raying, scanning and visually dissecting the monument in the hope of enlightenment has been avoided. Under the circumstances of the original investigation, it may have been impossible to record more of the architecture of the tomb. But the effect 
is quite special, and perhaps in some ways particularly appropriate to how the built space of the tomb, inside the mound, actually works.

Fig. 15. From Tilley 1996:fig. 3.3. Photograph by George Nash.

An imaginative photograph that evokes quite a bit of the mystery with which ancient sites are sometimes surrounded. The dark forest in the background appears impenetrable, keeping its secrets. The topic and genre of the photograph are quite conventional, yet the picture is unusual in that presumably a good part of the monument (extending towards and to the right of the camera) cannot actually be seen in the picture, and those parts it does show are covered by a solid layer of snow. Inside the circle of stones a few plants are breaking through the smooth surface of snow, indicating that there is life underneath. No trace of human presence is visible in the picture, and yet we know at the same time how the fragile atmosphere of a site covered with snow can be destroyed by the deep footsteps of the visiting photographer/archaeologist.

Fig. 16. From Tilley 1996:fig. 3.21. Based on Hellman 1963:67.

The scale is larger here, in fact so large that the megaliths shown are represented by dots with a diameter of approximately $150 \mathrm{~m}$ in reality - if they were accurate to scale and not symbols for much smaller passage graves. Due to this
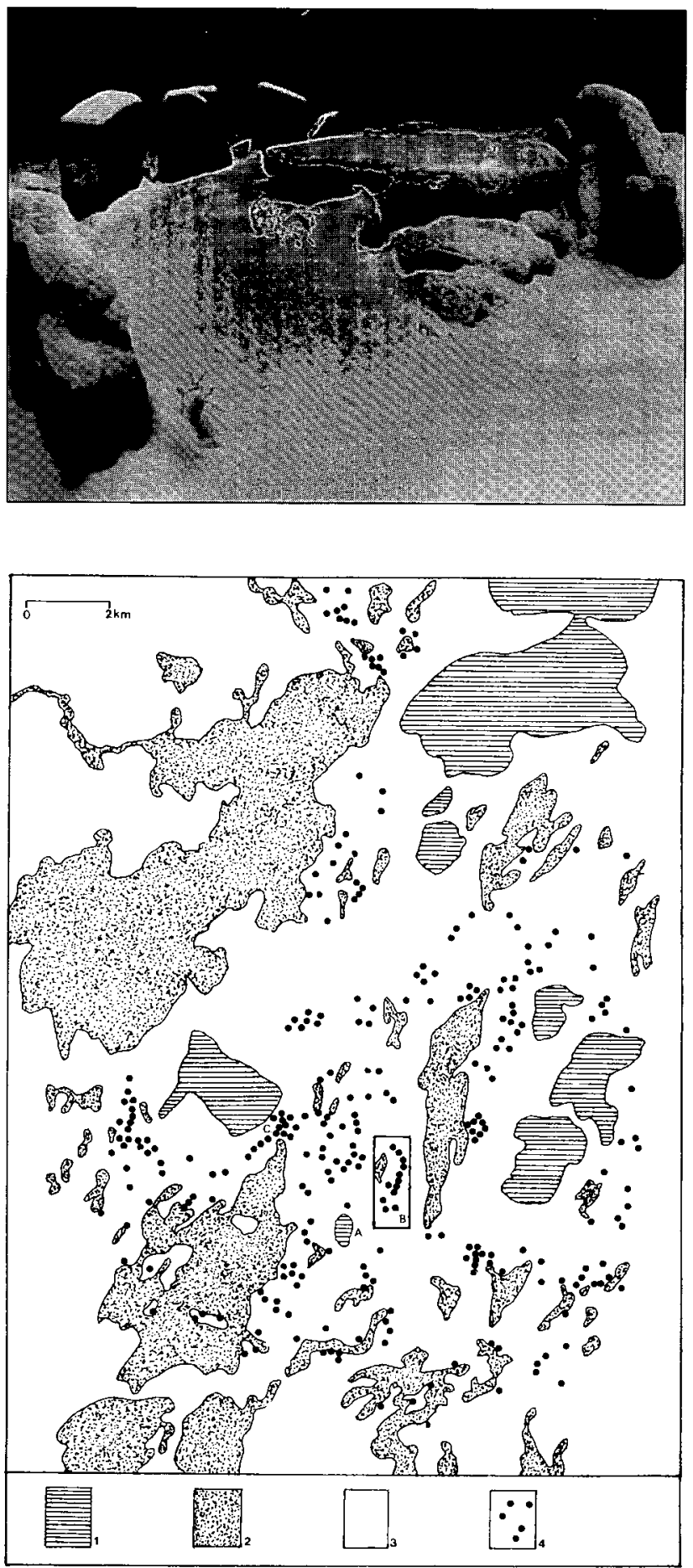

Figure 3.21 The distribution of passage graves in Vastergotland in relation to landscape features.

1: Flat-topped, steep-sided mount ain block of igneous rock, $2:$ Marshy areas, 3 : Limestone plateau,

4: Passage grave. A: Alleberg mountain. B: Inset refers to Fig. 3.30: Passage graves in the Karleby area C: Falköping area (sec Fig. 3.31) 
enormous scale, all sites now look the same: identical dots. The point of view is from high up in the sky - not a bird's eye but a spy satellite's camera. A high resolution satellite picture would nevertheless look very different. Not only would none of the sites be visible at that scale, but the landscape as a whole would be full of signs of human occupation and other details, and not feature a scale, letters, differently shaded areas, and an inset referring to another figure. This image gives the archaeologist a 'larger picture', but it is counter-intuitive and truly removed from how we, as human beings, normally see megaliths.
Fig. 17. From Tilley 1996:fig. 7.1. Photograph by Christopher Tilley.

The picture is captioned "The passage grave at Västra Hoby, western Skåne", yet what is most striking in it are a field covered with a fine layer of snow, five prominent trees without leaves, single-family homes on the outskirts of a village, and above everything a large if contourless sky. But those things are not supposed to matter. All we are supposed to look at as readers and observers appreciating the book of an archaeologist are a number of unspectacular stones and a mound which we can make out among and underneath the imposing trees. The difference be-

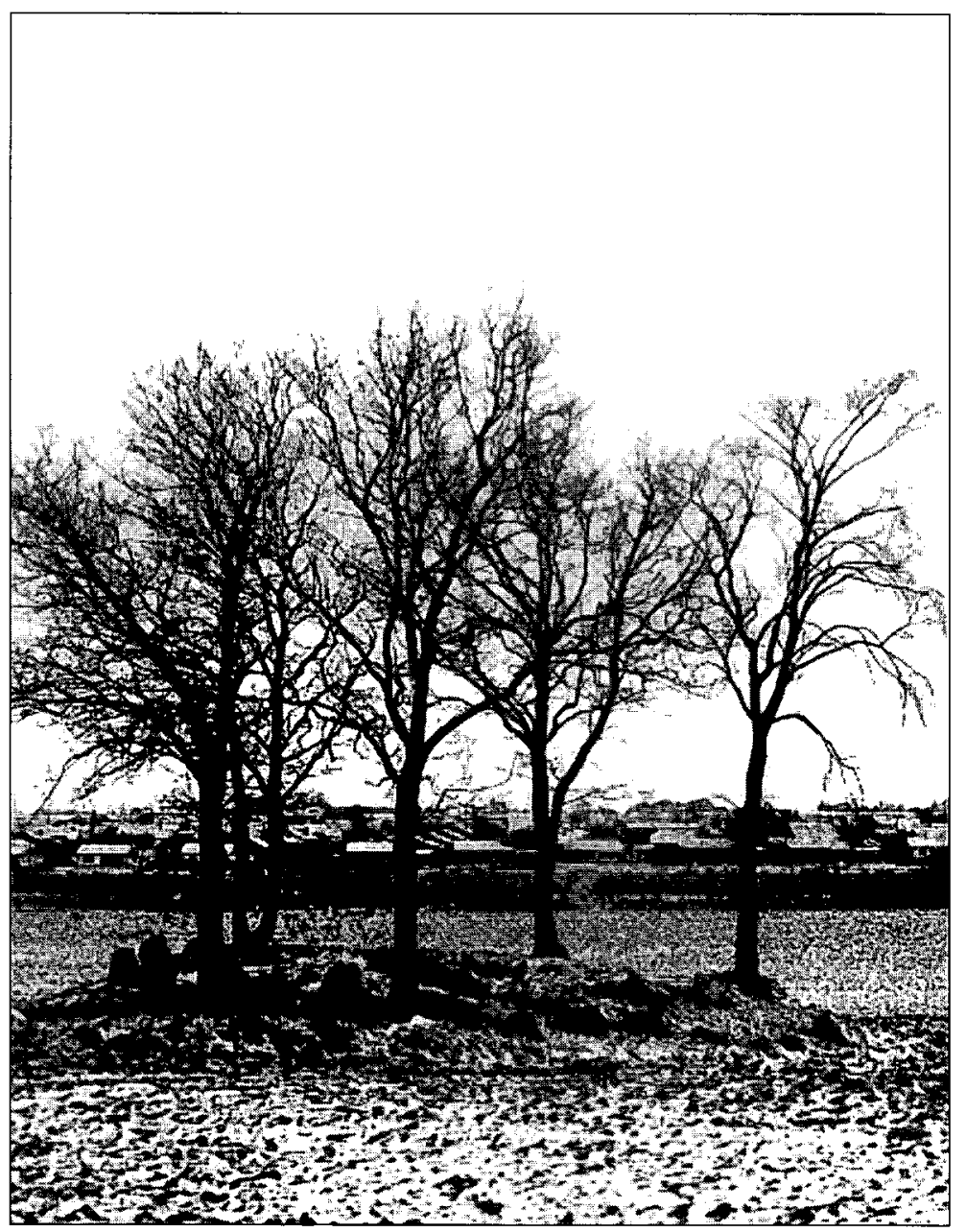


tween what the picture shows and what we are looking at could hardly be greater. But the trees are only seemingly in the centre of things. If it was not for the preserved, published, and protected monument neither would the trees in the middle of this field still exist, nor would the picture have been taken at all.

\section{* * *}

\section{A NEW PICTORIAL VOCABULARY?}

My discussion thus far should under no circumstance be seen as a form of criticism of the images or the archaeologists responsible. I have tried to present key aspects of the visual language for representing megaliths in twentieth-century Swedish archaeology. As much as we all use certain terms - and much can be said about their histories, functions, and insufficiencies (e.g. Thomas 1993; Tilley 1998) - we also use certain kinds of images which need to be looked at and studied just as carefully.

As we move into the twenty-first century we will undoubtedly see more of the kind of images that are already familiar to us in archaeology. As I have indicated, many of them have virtues that are not often appreciated. But likewise we can expect archaeologists to experiment and work with a new pictorial vocabulary. Håkan Karlsson (1998) recently used drawings by his small son as illustrations of abstract terms in a book on archaeological ontology - though he settled for conventionally drawn plans where he discussed two megaliths as case-studies. A book with many strikingly different images conveying experiences of the past that are quite independent from any written description, was published by Michael Shanks back in 1992. He included not only evocative photographs but also photomontages, collages, and water-colours. Taking up the theme again in 1997, Shanks argues that "the ability to sample, quote, and seamlessly manipulate the visual world offers great scope for presenting pasts of richer texture, more attuned to our contemporary selves, and more edifying" (1997:74). In a similar spirit, but focussing on the archaeologists themselves, Jens-Erik Larsen contributed photographic snapshots of archaeologists at work to a fascinating account of an archaeological field project in northern Norway (Larsen et al. 1993). Another project experimenting with ways of understanding archaeological practice has been conducted since 1996 by Jonathan Bateman within the Gardoms Edge Landscape Project in the Derbyshire Peak District of England. His photographs visualise how archaeologists interact with the site, their tools, each other, visitors etc. They have been exhibited on the site itself, in the Department of Archaeology and Prehistory, and in the Graves Gallery, both in Sheffield (Bateman pers. comm.). Some of Bateman's snapshots of the material culture of an excavation are also accessible on-line (www.shef.ac.uk/ assem $/ 2 / 2$ cntrfld. html; www.shef.ac.uk/ $\sim$ assem $/ 3 / 3$ fold.htm; www.shef.ac.uk/ assem/ 4/4cent.html).

In a recent conference session, Cole Henley (1998) discussed the problems he sees with conventional archaeological illustrations. According to Henley (and Shanks 1997), archaeological illustrations seem to have avoided the ideas and issues that have been so successfully considered in recent texts about interpretation, objectivity, representation, embodiment, the individual, and gender issues, among other themes. Henley therefore calls for "illustrating from a first person perspective", the inclusion of acting people, ethnographic objects, and generally more colours in archaeological images. This has been tried, for example, by Ruth Tringham in her efforts to 'engender' prehistoric house sites at Opovo, Yugoslavia, through the media of narratives and visual imagery (Tringham 1994:190-198). While there may be technical and financial limitations as to what kind of images can be reproduced in print, Vicky Cummings (1998) argued that 
the World Wide Web may offer more opportunities for experimenting with new kinds of images showing archaeological sites and landscapes. This includes the use of colour, video, interactive GIS, virtual reality and the possibility for the reader to move around large panoramas by using the mouse.

Barbara Bender, Sue Hamilton, and Christopher Tilley (ca. 1998), who work together at Leskernick in south-west England, have been discussing archaeological documentation and representation in terms of contemporary art. In an effort to represent their experiences of the site, and capture the powerful sense of place, they have been actively engaged in forging "a middle way between the personal idiosyncratic approach to landscape characteristic of contemporary artists and the disengaged and disinterested 'objectivity' of visual representation in contemporary archaeology." This ambition has, for example, led to photographs of spoil heaps, of stones which had been wrapped in cling film and painted, and of the archaeologists' shadows on the stones. Pictures of the landscape at Leskernick include views through a wooden doorway brought to the site, and of houses and field walls marked with bright red, green, and yellow flags. In another initiative, Tony Williams (1999) invited participants of the Leskernick project to each take one photographic snapshot of a place that was important to them on the site, and that conveyed a 'sense of place'. The resulting photographs and accompanying explanations expressed the individual engagements with the site of Leskernick. Some of these experimental images from the Leskernick project can be seen at the project web page (www.ucl.ac.uk/leskernick).

In this paper I hope to have been successful in reviewing some main ways in which megaliths have been depicted in twentieth-century Swedish archaeology. However, entering the third millennium of our chronometrical timescale should not only be an occasion to look back, but also an opportunity to look forward and reflect upon the way ahead. Recent discussions about the problems with established ways of depicting archaeological sites and objects, and suggestions for new kinds of images and illustrations, should concern us all and lead to an active engagement of archaeologists with questions of visual (re)presentation. In what sort of images megaliths will be depicted in Swedish archaeology of the next century remains to be seen!

\section{English revised by Laura Wrang.}

\section{ACKNOWLEDGEMENTS}

This paper was researched and written while I held a STINT Visiting Scholarship at the Institute of Archaeology, University of Goteborg. I am very grateful to Jonathan Bateman, Jarl Nordbladh, and Karl-Göran Sjögren for commenting on earlier versions of this paper and improving it in many places. Karl-Göran Sjögren also helped with finding the right literature. Cole Henley was kind enough to send me his unpublished TAG paper. The ustual disclaimers apply. 


\section{REFERENCES}

Baigrie, B. S. (Ed). 1996. Picturing Knowledge. Historical and Philosophical Problems Concerning the Use of Art in Science. Toronto.

Bateman, J. In preparation. Words and Pictures: Images as discourse in archaeology. Doctoral thesis in preparation. Department of Prehistory and Archaeology, University of Sheffield.

Bender, B., Hamilton, S. \& Tilley, C. Ca. 1998. Art and the Re-presentation of the Past. http:/ /www.ucl.ac.uk/leskernick/articles/art/art. htm (accessed 18 February 2000).

Blomqvist, L. 1989. Megalitgravarna i Sverige. Typ, tid, rum och social miljö. Stockholm.

Bradley, R. 1997. 'To see is to have seen': Craft traditions in British field archaeology. In: Molyneaux, B. L. (Ed). The Cultural Life of Images. Visual Representation in Archaeology. Pp. 62-72. London.

Cullberg, C. 1963. Megalitgraven i Rössberga. Stockholm.

Cummings, V. 1998. Understanding and representing the landscape: a case-study from Neolithic South Uist. Paper given at the Theoretical Archaeology Group Conference, Birmingham 1998. http://www.cf.ac.uk/uwc/ hisar/people/vc/tag98.html (accessed 18 February 2000 ).

Ellenius, A. (Ed). 1985. The Natural Sciences and the Arts. Aspects of Interaction from the Renaissance to the Twentieth Century. An International Symposium, Uppsala 1983. Stockholm.

- (Ed). 1990. Bilden som källa till vetenskaplig information. Kungl. Vitterhets Historie och Antikvitets Akademien, Konferenser 23. Stockholm.

Forssander, J.-E. 1936. Skånsk megalitkeramik och kontinentaleuropeisk stenålder. Meddelanden från Lunds universitets historiska museum. Reprinted in: K. Human. Vetenskapssamf:s i Lund Arsberättelse 1935-36. Pp. 203279.

Hårdh, B. 1990. Patterns of deposition and settlement: studies on the megalithic tombs of West Scania. Scripta minora Regiae Societatis humaniorum litterarum Lundensis 1988/ 1989:2

Hellman, G. A. 1963. Västergötlands gånggrifter. Falbygden 18. Pp. 65-74.
Henley, C. 1998. Is all art quite useless: postprocessualism in representing the past. Paper given at the Theoretical Archaeology Group Conference, Birmingham 1998.

Karlsson, H. 1998. Re-Thinking Archaeology. GOTARC Series B. Göteborg.

Larsen, J.-E., Olsen, B., Hesjedal, A. \& Storli, I. 1993. Camera archaeologica. Rapport fra et feltarbeit. Tromsø Museums skrifter XXIII.

Lindqvist, S. 1911. Två västgötska grafbyggnader från stenåldern. Fornvännen. Pp. 126-140.

Lynch, M. \& Woolgar, S. (Eds). 1990. Representation in Scientific Practice. Cambridge, MA and London.

Molyneaux, B. L. (Ed). 1997. The Cultural Life of Images. Visual Representation in Archaeology. London.

Montelius, O. 1910. Falbygdens fornminnen. In: Falköping förr och $n u$. Pp. 57-77. Falköping.

Moser, S. 1999. Ancestral Images. The Iconography of Human Origins. Phoenix Mill.

Moser, S. \& Gamble, C. 1997. Revolutionary images. The iconic vocabulary for representing human antiquity. In: Molyneaux, B. L. (Ed). The Cultural Life of Images. Visual Representation in Archaeology. Pp. 184-212. London.

Nordbladh, J. 1997. Conducteuren C. G. G. Hilfeling och hans samtid. In: Åkerlund, A., Bergh, S., Nordbladh, J. \& Taffinder, J. (Eds). Till Gunborg - arkeologiska samtal. Pp. 527537. Stockholm Archaeological Reports 33.

Piggott, S. 1978. Antiquity Depicted. Aspects of Archaeological Illustration. London.

Rydbeck, O. 1932. Stenkammargravar i Barsebäck. In: Arkeologiska studier tillägnade H.K.H. Kronprins Gustaf Adolf. Pp. 28-47. Stockholm.

Sahiström, K. E. 1939. Valle härads fornminnen. Skövde.

Shanks, M. 1992. Experiencing the Past. On the character of archaeology. London.

- 1997. Photography and Archaeology. In: Molyneaux, B. L. (Ed). The Cultural Life of Images. Visual Representation in Archaeology. Pp. 73107. London.

Strinnholm, A. L. 1995. En anekdot kring en legend: om Montelius och Retzius utgrävningar i Karleby. Arkeologen 1 (3), 18-19.

Strömberg, M. 1968. Der Dolmen Trollasten in 
St. Köpinge, Schonen. Bonn/Lund.

- 1972. Die Megalithgräber von Hagestad. Zur Problematik von Grabbauten und Grabriten. Bonn/Lund.

Thomas, J. 1993. Discourse, totalisation, and 'the Neolithic'. In: Tilley, C. (Ed). Interpretative Archaeology. Pp. 357-394. Oxford.

Tilley, C. 1996. An ethnography of the Neolithic. Early prehistoric societies in southern Scandinavia. Cambridge.

- 1998. Megaliths in Texts. In: Edmonds, M. \& Richards, C. (Eds). Understanding the Neolithic of North-western Europe. Pp. 141-160. Glasgow. Virtually identical text in: Tilley, C. 1999. Metaphor and Material Culture. Pp. 82-101. Oxford

Tringham, R. 1994. Engendered Places in Prehistory. Gender, Place and Culture 1, 169 203.
Trotzig, G. 1987. The Introduction of Photography into Swedish Archaeology. In: Burenhult, G., Carlsson, A., Hyenstrand, A. \& Sjøvold, T. (Eds). Theoretical Approaches to Artefacts, Settlement and Society. Studies in honour of Mats P. Malmer. British Archaeological Reports, Int. Ser. 366 (I). Pp. 73-86. - 1990. Arkeologins bildbruk. In: Ellenius, A. (Ed). Bilden som källa till vetenskaplig information. Kungl. Vitterhets Historie och Antikvitets Akademien, Konferenser 23. Stockholm. Pp. 105-124.

Williams, T. 1999. Imaging the self: photography at Leskernick. http://www.ucl.ac.uk/ leskernick/gallery/imaging/im-text.html (accessed 22 February 1999).

Wrangel, E. 1938. Svenska folket genom tiderna. Malmö. 
